DOI: http://dx.doi.org/10.4314/ljh.v26i1.7

\title{
The Revolutionary Poems of Tayo Olafioye
}

\author{
Clement Eloghosa Odia \\ Lecturer, Department of English and Literature, \\ University of Benin, Benin City, Edo State, Nigeria.
}

\begin{abstract}
This paper examines the revolutionary poems of Tayo Olafioye in order to demonstrate how his radical thought is depicted in his poems. To achieve this purpose, a study of one of his collections of poems, entitled A carnival of looters, is undertaken. In the study, we discover that proverbs are the central technique used in depicting critical ideas in the poems. The paper concludes that proverbs are used for expressing reformative messages as means of mobilisation and conscientisation of the masses in order to achieve social change.
\end{abstract}

Keywords : revolution, mobilisation, conscientisation, proverbs, physicalism

The social function of art resides in its capacity of inciting revolution, which has been described as 'the instrument of rescuing society from its social doldrums' (Akano, 2013, p.66). In the light of Akano's affirmation (2013), we intend to push this argument a little further, by showing that proverbs are used to express revolutionary thought in the poems of Tayo Olafioye. Akporobaro (2005) has asserted that proverbs are 'a means for deepening and generating ...awareness' (p.74) and that because of this, they are used to perform a 'very wide educative role.' Akporobaro (2005, p.87) further contends that 'most Nigerian proverbs are expressions of feelings or opinions or intended to influence people's wills and actions'. This potentiality is what Olafioye has exploited to articulate the revolutionary message in his poetry.

Additionally, Finnegan (2012) states: 'proverbs, then, may be a particularly suitable form of communication in situations and relationships of potential or latent conflict' (p.400). As explosive as revolutionary situations are, proverbs become imperative in conveying the poet's ideas. In the context of this paper, we intend to establish the fact that proverbs are used to educate the masses. 


\section{The Concept of Revolution}

Heywood (2007) focuses on the causes of revolution. In his opinion, people embark on a revolution for several reasons. He identifies four specific reasons:

Revolutions are popular uprisings that consist of extra-legal mass action aimed at changing the political system. Revolutions have been explained in a variety of ways. They have been portrayed as a symptom of a supposedly deeper social transformation, as a sign of disequilibrium in the political system, as a consequence of the thwarting of rising expectations, and as a result of the declining effectiveness of the state. (p.225)

From Heywood's point of view, a revolution could take place when certain social expectations are not met by the leaders. In the same way, when the political system encourages the unequal treatment of people, revolutions will occur. In addition, revolutions can become the order of the day where the state continues to show weakness in most aspects of its national life. Consequently, it leads people to seek better alternatives.

Heywood (2007) also emphasises the violent nature of revolution. Although violence may form the nucleus of a revolution, it is regarded as a means of actualising change rather than the change itself. He declares further: "the concept of "revolution" can be regarded as an ideal type in this sense in that it draws attention to a process of fundamental and usually violent political change' (p.18). The idealistic quality of revolution, as noted by Heywood, underscores the need for a process-oriented approach to change. For, no meaningful revolution can take place without a thorough plan.

For his own part, Hoover (2007) articulates Edmund Burke's preoccupation with how a revolution could be achieved: 'Burke was, in fact, more concerned with the method of change than with the agent. The political method he prefers is gradual, responsible, and carefully considered'(p.57). Hoover's idea (2007) of revolution places emphasis on the method. Buttressing Heywood's (2007) process-oriented approach, Hoover submits that effective revolutions must be gradual, responsible and properly thought out. What this means is that it must be a product of the mind (intellectualism) and not of the fist (physicalism).

Calvert (1996) believes that revolution and violence are inseparable. He explains: 'the idea of violence, real or threatened, is inseparable from it' (p.2). He adds: 'The word "revolution" has more specifically come to mean a major change in the political and socio-economic structure of an individual state, brought about by the spontaneous efforts of its citizens, though these efforts may be aided from outside and may in turn act to bring about similar changes in other countries' (p.2). 
In Calvert's view, a revolution is synonymous with a major political and socioeconomic change in the structure of a particular nation-state; such a change is often brought about by internal forces, as well as by outside forces. In other words, the citizens can expedite the process of change working in concert with other nationals in order to bring about revolution.

Finally, Nielsen (1979) examines the implication of the economic factor in a revolution. For him, a revolution results when the economic structure fails to sustain and satisfy the hopes and expectations of the people: 'For there to be a revolution, it is often claimed, there must be widespread misery, deprivation, and exploitation followed by a brief period of rising expectations which, after some minor improvements in the oppressed people's condition, are in turn dashed by a turn of events for the worse' (p.160). Thus conceptualised, a revolution is justified when the leaders have failed to prevent widespread misery, deprivation and exploitation. Where these prevail, the masses can embark on a revolution to usher in the much needed change. It is against this background that this paper identifies mobilisation and conscientisation as the primary functions of proverbs in Olafioye's revolutionary poems.

\section{Review of Scholarship on Tayo Olafioye's Poetry}

Okome (2000) is among the scholars who have examined Olafioye's A Carnival of Looters locating the poems within the border of patriotism and recognising the deep socio-political thrust underpinning the message of the poems: 'A poet of the younger generation, his overriding concern is for the future of nationhood and national identity; and his own relationship to the nation as a committed poet writing in exile. The poet assumes that to love one's country is to be critical about its hateful history, disintegration and idiocies' (p.39)

Okome's critique outlines Olafioye's patriotic inclinations and the possibility of achieving social change. The study pays adequate attention to the poet's portraiture of nationhood and national identity. Okome's study does not, however, reveal the path to national freedom.

For his part, Uzowulu (2014) carries out a comparative study of the poems of Olafioye and Niyi Osundare. According to him, 'In Tayo Olafioye's A Carnival of Looters, we learn of the evils of corruption, the helplessness and the disaster it brings. The poet presents us with the different faces of corruption political, economic and moral corruption which is prevalent in the Nigerian society' (p.49).

According to Uzowulu, Olafioye's poems capture the different shades of corruption practiced in Nigeria. From the poet's range of imagination, no aspect of the society is spared. Adding to the above, Uzowulu submits: 'What angers the poet the most is Nigerians' attitude to corruption. He tries to incite anger in Nigerians. He says our complacent attitude and mythical beliefs will not save us from corruption' (p. 50). From 
what we can gather, Uzowulu's paper is more concerned with identifying the causes of corruption rather than how it can be eradicated. In many respects, Uzowulu's research, like Okome; s appraisal, fails to explain how change can be created.

In a sociological study of Olafioye's poems, Temiloluwa (2011) states thus:

Olafioye is a satirical poet who uses his choice of words to convey his message in his satirical poems to elaborate and emphasise the situation of his nation. He employs metaphorical phrases to reveal truths. An example of his quest for truth was evident in his use of the proverbial Aiyekooto, the parrot - known for truth as the only way for Nigeria's socio-economic resurrection. (p.47)

Although Temiloluwa recognises Olafioye's use of proverbs, she does not show the relevance of proverbs to the overall purpose of the poems. Like other scholars who have worked on Olafioye's poems, these statements are not given adequate textual illustrations from the poems.

Akano (2013), another Nigerian critic, seeks to show that Olafioye's poetry censures socio-political realities in Nigeria. He contends, 'Olafioye, a victim of sociopolitical malaise and strangulating economic crunches castigates using aesthetic grenade that has been the cupful lots of his native land. His poetic bi-focal lens picture with utmost consternation his rabid passion with which the country's socio-political landscape has been awash' (p.67). Akano's analysis is concerned with revealing the problems confronting the Nigerian society without demonstrating from the poems how the poet intends to solve the said problems. While my paper has immensely benefitted from the insights provided by these studies on Olafioye's poetry, it attempts to transcend current literature on his craft by highlighting mobilisation and conscientisation as the primary functions of proverbs in Olafioye's revolutionary poems.

\section{Mobilisation}

Proverbs, in Olafioye's poems, are used for mobilising the masses in order to achieve political revolution. A noteworthy attempt to project this idea is to be found in the poem entitled 'Lunatic cuckoos.' The poem opens with an unusual frankness that jars the leader's complacency and awakens his/her sense of guilt:

We are all patients

in the hospital of guilt, dancing together in sadness.

Difficult to be sorry, society deserves government it gets. (p.36) 
The speaker gains our trust by using the possessive pronoun 'we'. In effect, he identifies with our sense of collective guilt. The poet enriches the poem with the image of sickness, sadness and suffering which have taken a national dimension. To him, this sickness is a product of the visionless government that has been entrenched in Nigeria.

To buttress the point that every society deserves the kind of government it gets and to justify his condemnation of the people, the speaker introduces a fitting proverb: 'no one sits so idle/when their home is ablaze' (p.36). What this means is that it is sheer lunacy for anyone to do nothing when their home is on fire. In the view of the speaker, Nigeria is burning terribly but unfortunately, Nigerians sit on the fence and do nothing. Therefore, by their inaction and indecision, they do not only condone bad governments but also permit them to thrive. This proverb is fittingly used to condemn Nigerians and also to indirectly nudge them into revolutionary action.

Olafioye's (2000) uniqueness and much of his success lie in the baffling and completely unexpected juxtapositions he makes of indifference and disloyalty:

\author{
Dead, of course; \\ loyalty to nation; \\ principle and \\ conviction. (p.36)
}

The proverb that immediately follows the above excerpt captures the absolute loss of patriotic commitment in the Nigerian nation. His presentation of Nigeria as a nation with no patriots, no principles and no conviction conveys the impression that Nigeria is a nation enmeshed in moral attrition. As a corollary, such a nation is only tending carcass to its citizens and cannot achieve national development. This is what the proverb below appears to be saying:

\title{
Only those tending the carcass await their spurious harvesting. (p.36).
}

There is nothing that can come out of waiting for change as long as the leaders prefer to manage the carcass of the nation for their own good.

The speaker draws the attention of the reader to one fundamental error of his compatriots and that is, the predisposition of Nigerians to 'haste[n] to change the guards' (p.30) without first changing their 'national attitudes'. It is not enough to replace one leader with another. The citizenry has everything to gain by discarding the old unpatriotic attitude and embracing loyalty, principle and conviction in the country. It is on this premise that Nigeria can become the dream of what Nigerians aspire to actualise. 
Olafioye's use of precise epithets creates a certain lushness as when he describes the nation's three major ethnic groups:

Spineless Yorubas
diplomacy degenerate:
strong-willed Igbos
bullish myopia
Sissy Hausas
hegemonic manipulators
triumvirate ills
in a national petri dish;
lunatic cuckoos, all (p.37)

The speaker identifies the different challenges that have plagued the three major ethnic nationalities in Nigeria: spinelessness, myopia and hegemonic manipulation. The masses are encouraged to lay aside these differences in order to achieve political revolution. The poem ends with an apt proverb: 'Nothing happens for good by itself' (p.37). This proverb suggests that for change to happen, it must be made to happen. Nigerians are urged to follow the examples of nations that have achieved freedom from misrule. The persona makes a list of some of them:

Nothing happens for good by itself

Albania;

Somalia;

Mozambique;

Kurdistan;

Chechnya;

Bosnia;

Liberia;

What have we? (p.37)

By listing these countries, the speaker is indirectly mobilising the people to emulate their citizens who have made so much sacrifice to rid their countries of bad leaders and achieve social change.

Always remarkable for his quest for social change, Olafioye, in another poem entitled 'My patriotic quest', emerges as a poet endowed with great vision. Olafioye's proverbs could be described as exemplary in general. In particular, they demonstrate the fact that they possess paradoxical quality: 
Silence is graveyard of hope.

But...

How do you ask ancestors

Why the country we love

now sour and a firestorm -

sand dunes suffocating the sea? (p.20)

The opening line exemplifies the use of the paradoxical proverb. It scolds the Nigerian people for their silence in the face of extreme oppression from the government. 'Silence' is equated with a 'graveyard' where 'hope' is buried. Thus, this statement can be interpreted as: silence buries hope. This is an indirect attack on all those who choose to remain silent where their voice is required. The poet's persona later reveals the various experiences of the people. Through apt diction, the speaker highlights the hardship of the people. The word 'sour' conveys the sense of economic hardship that has taken root in Nigeria and is commonly experienced by the poor. As for the 'firestorm' and 'sand dunes', which are said to be 'suffocating the sea' of Nigerian people, they symbolise the political repression that has been unleashed on the masses by the military government in Nigeria.

The second proverb: 'Nothing happens by itself', is an indirect mobilisation of the people against a catalogue of social reverses. The angry tone of the speaker takes a more belligerent dimension as he uses rhetorical questions to accentuate the condition of the people:

How do you ask ancestors?

why born a nation

that rows backwards in

the boat of progress?

How do you write your pains?

in words of comfort

for the hungry and dying?

Tribal phantoms of social lepers. (p.20)

This poem contains a sizzling dose of imagery and figurative language. The imagery is spontaneous; instinctive, a flash of imagination, going poetically against logic. The imagery reflects the poet's vast experience and knowledge. In this poem, Olafioye's sense of awareness is intimately felt:

How do you sing a people demoralized and broken, 
breathing fiery droughts

in their nostrils?

How do you pray for hope:

a nation

ruled by demons

with hairs between teeth? (p.20)

The provocative images in this poem are meant to incite the reader against their oppressive leaders who cannot appreciate reason. Consequently, the poem condemns docility, indifference and the pathological waiting among Nigerians for something to happen or the baseless hope for change that the people are unprepared and unwilling to create.

In another poem entitled 'The pathology of hope', the poem mobilises the masses to embrace revolution in order to bring about change. This is expressed beautifully through proverbs. The poem berates the general public thus:

We stagger,

disaster to disaster,

blind to the batter self.

Only the parasites cheer

in the festival of loot. (p.21)

The people are portrayed as those who stagger from one disaster to another as those who gain from the looting celebrate their success endlessly. He then condemns those who exhibit misplaced hope that God will right their wrongs and change things for the better:

Unwilling to pay the price;

to save ourselves;

to save the nation.

Ours: the pathology of hope;

ours: the pathology of myths

managing the misery

of human condition,

no matter the evil;

we must 'manage'. (p.20)

Consequently, the speaker derides the people for lacking the courage to pay the price for freedom. In consequence of their inaction, the people keep enduring misery, corruption, 
hopelessness, helplessness and haplessness till, the day, everyone ends up dead. It is against this context that the two proverbs which end the poem become meaningful:

\author{
Death has no assignment \\ in a deserted home. \\ When ancestors lived, \\ Masquerades balanced \\ Masks on own heads \\ Without backed assistance \\ of illiterate guns. (p.22)
}

The first proverb speaks to the masses to abhor the sense of resignation to fate and to take action. Additionally, it expresses disgust at those who take solace in hope as nothing can be done after death has destroyed their lives. In the second proverb, the persona emphasises the need for self- help or self-reliance in the quest for freedom. Using the image of a masquerade, the persona compares the way masqueraders wear their masks unaided to explain why Nigerians must help themselves without first seeking for outside help. Therefore, they are encouraged or mobilised to fight the system on their own.

\title{
Conscientisation
}

One predominant feature of Olafioye's revolutionary poems is the use of proverbs to conscientise the people about their common enemies, the political leadership. This fact speaks for itself in the poems. One such poem is entitled 'Mandela berates Nigeria' and it begins as follows:

\author{
The generals thought \\ everyone a sergeant major \\ their boot camps; \\ poison of the rum, \\ in the gumption; \\ the hemlock of air headedness. (p.43)
}

The real significance of this is that Olafioye has an unusually keen eye or rather, an astonishing precocity to create very clear images for us. The poison image is used to portray the generals as destructive. In this poem, the poet succeeds in impressing us with the viciousness of the generals towards the people.

The poem censures the military junta revealing how they have brought Nigeria into disrepute. In the speaker's opinion, Nigeria has suffered much. Six proverbs are used to conscientise Nigerians: 
The MAN tamed wilder howlings

An old woman not old,

When it's the dance she knows. (p.43)

The first proverb above is used to substantiate the fact that military dictators have sufficient experience in crushing protests and dissenters. The image of dance buttresses the fact that the military leaders are quite comfortable in putting down revolutionary reactions from the people. In the second proverb, the persona draws the attention of the leaders to the foolhardiness in thinking that the world is not watching:

That which an old man sees, sitting down, the young cannot, standing up. (p.43)

The contrast between the old and the young is meant to ridicule the apparent wisdom of the young military officers in power and to imbue in the masses the superior power of the advanced nations who obviously are watching and, of course, waiting for Nigerians to start the revolution. The third proverb reveals the absurdity of Nigeria's position in Africa as a giant nation. This proverb emphasises the major factor responsible for the shameful fall of the nation: inaction. According to the persona,

Nigeria, the giant,

now, a minion pariah.

When pride, before humility, always a head dive. (p.43)

What distinguishes this poem artistically is the ironic perspectives, which when viewed clearly, provides a sufficient cause for rejecting the military leaders in power.

Through a dose of three proverbs combined to form the concluding stanza, the speaker conscientises the masses to dare the military government so as to rid the country of their menace:
A hen cannot attend marriage ceremony, where the fox presides. He who is not afraid of the lion, let him touch its tail. Rude chicken will be 
sober in the pot of stew. (p.44)

The first proverb shows the incompatibility and the unnatural situation that exist in a nation like Nigeria blessed with great minds and yet presided over by blood-thirsty and self-seeking rulers. Through this apt proverb, the people are encouraged to reject such leaders. The speaker also cautions the people not to confront the military blindly, reminding them of the consequences of such untoward bravado.

In another poem entitled 'Usurpers: No basket holds water', the irrepressible tone of the speaker amplifies the proverbs as they help educate the masses:

No matter how long the night, dawn will surely come.

We know

You live at the bank of the river; disdain washing your hands with saliva.

You water your gardens

with the sweat of the people.

It is the mouth that coughs

that draws death to itself. (p.38)

This poem is rooted in deep Yoruba proverbs which become the channel for the transmission of the revolutionary message to the reader. For example, the opening proverb expresses the timeless aphorism that no matter how long the night may be, it must climax in dawn. By extension, the speaker is saying that no matter how long the reign of political impunity and misrule may last, it must end one day. The masses are, therefore, encouraged not to lose hope but to keep up the struggle knowing that the oppression will not last forever. Also, readers are made aware of the popular saying that one cannot live by the river and be expected to wash one's hands with spittle:

You live at the bank of the river;

disdain washing your hands with saliva. (p.38)

This is a direct call to rebellion. The masses are reminded that they live at the bank of immeasurable river of abundant wealth and as such, they must refuse to live as paupers. The definiteness and absoluteness of 'disdain' confirms, in effect, the revolutionary attitude which the speaker wants the masses to appropriate in order to end all forms of exploitative tendencies and reflexes on the part of their leaders.

In 'Parliament of idiots', Olafioye continues to conscientise the masses through the use of proverbs. The poem begins thus: 


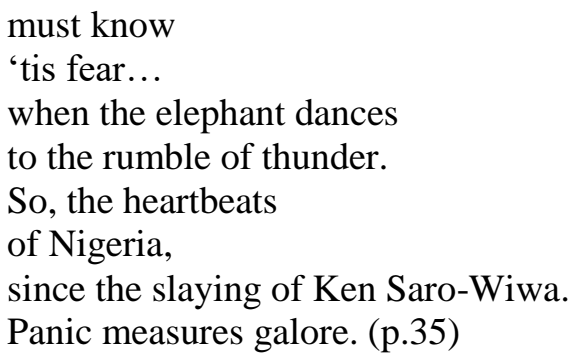

The speaker recreates the prevailing mood in the country at that time when Ken SaroWiwa, the famous environmental activist, was slain during the infamous Abacha regime. The upheaval that followed Saro-Wiwa's death is tacitly conveyed: the closure of universities, the demonstrations across the country and other reactions that shook the foundations of the country.

Consequently, the speaker tells the masses:

They forget, as custom:

you cannot hide nakedness

from those destined

to bury you. (p.35)

The proverb above touches the heart of the message. The speaker through this proverb is assuring the masses that the regime will definitely crumble no matter how hard the oppressors hang on to power. In effect, it foretells of the inevitable general change that will sweep through the country. This proverb demonstrates the poet's prophetic gift as well as expresses the fact that no matter how long the leaders (military) try to hide their exploitation, it will never be forever.

The leaders are cautioned:

Better to make kings

of new dawn,

a fresher dawn.

Each society craves the sun

why not yours? (p.35)

The images of the sun and that of dawn reveal the revitalising power of change to shed light on the darkness that has overshadowed the progress of Nigeria. The brilliance of the poem immediately comes to life with the effective use of a rhetorical question. This question is moralising as well as conscientising in its conception. Insofar as change is 
every sane society's obsession, the speaker is persuaded that should be the national emblem of Nigeria.

\section{Conclusion}

This paper has examined the revolutionary poems of Tayo Olafioye. It has argued that his revolutionary thoughts are expressed through the use of proverbs for the twin goals of mobilisation and conscientisation.

To effect mobilisation and stir the masses to effect social change, proverbs are made the fulcrum of Olafioye's poems. One of the methods employed in this regard is by using speakers who expose the atrocious activities of the government. In each case, proverbs which scold the people's reticence and silence in the face of provocative leadership are effectively deployed.

In addition to mobilising the masses, proverbs are used for conscientisation. This functions by using speakers who systematically use proverbs that are analogous to the content, thus helping to contextualize, clarify and deepen the message. The proverbs are directed to encourage, to spur and to educate the masses.

From the above, it is clear that proverbs are not a mere appendage in Olafioye's works. Rather, they are at the very heart of his poetry. Thus, proverbs are vital to Olafioye's revolutionary message. Their relevance can also be perceived in the area of expressing revolutionary thought in his poems. For this reason, proverbs are indispensable to the poetry of Olafioye in their artistic conception, thematic orientation and structural relevance. 


\section{References}

Akano, K.R. (2013). Socio-political vision and aesthetic mediation in Tayo Olafioye's A carnival of looters. Journal of the Literary Society of Nigeria,5,67-71.

Akporobaro, F.B.O. (2005). Introduction to African oral literature. Lagos, Nigeria: Princeton Publishing.

Calvert, P. (1996). Revolution and international politics( $2^{\text {nd }}$ ed.) London, UK: Pinter.

Finnegan, R. (2012). Oral literature in Africa. Cambridge, UK: Open Book.

Heywood, A. (2007). Politics ( $3^{\text {rd }}$ ed.) New York, NY: Palgrave Macmillan.

Hoover, K.R. (1994). Ideology and political life ( $2^{\text {nd }}$. ed.). Belmont, CA: Wardworth.

Nielsen, K. (1979). On the choice between reform and revolution. In H. J. Johnson, J. J.

Leach, \& R. G. Muehlmann (Eds.), Revolutions, systems and theories: Essays in political philosophy (pp. 155-176). Dordrecht, Netherlands: D. Reidel Publishing.

Okome, O. (2000). When will this carnival for looters end? Notes on Tayo Olafioye's A carnival of looters. Ibadan, Nigeria: Kraft Books.

Olafioye, T. (2000). A carnival of looters. Ibadan, Nigeria: Kraft Books.

Temiloluwa, O.O. (2011). Satire in contemporary Nigerian poetry: A study of Tayo Olafioye's Acarnival of looters and Musa I. Okpanachi's The eaters of the living. (B. A. Project). University of Ilorin, Nigeria. Retrieved from www.unilorin.edu.ng/studproj/arts/0715cd155.docx

Uzowulu, M.C. (2014). Corruption in Olafioye's A carnival of looters and Osundare's Songs of the marketplace. (B.A. Project). University of Benin, Nigeria.

Submitted: November 12, 2015 / Published: May 30,2016 